\title{
Vertical electrical sounding to delineate the potential aquifer zones for drinking water in Niamey city, Niger, Africa
}

\author{
Joy Choudhury ${ }^{1, *}$, K Lohith Kumar ${ }^{1}$, E Nagaiah ${ }^{1}$, S Sonkamble ${ }^{1}$, \\ Shakeel Ahmed ${ }^{1}$ and Venay KumaR ${ }^{2}$ \\ ${ }^{1}$ CSIR-National Geophysical Research Institute, Groundwater Building, Uppal Road, Hyderabad 500 007, India. \\ ${ }^{2}$ Super Geo Drillers, H. No. 632, Issabery Road, Plateau, Niamey, Niger. \\ *Corresponding author. e-mail: joy8099@gmail.com
}

MS received 9 November 2016; revised 24 March 2017; accepted 4 April 2017; published online 6 September 2017

Niger is a landlocked African country and the only source of surface water is the Niger River which flows in the western part of Niger and only few villages near to the river gets benefited from it, leaving most of the areas dependent on groundwater solely. The groundwater resources in Niger are mainly used for drinking, livestock and domestic needs. It can be observed that the water exploitation is minimal there due to several factors like undeveloped areas, less population, limited wells, rain-fed irrigation, etc. The delineation of potential aquifer zones is an important aspect for groundwater prospecting. Hence, the direct current (DC) resistivity soundings method also known as vertical electrical sounding (VES) is one of the most applied geophysical techniques for groundwater prospecting that was used in the capital city, Niamey of Niger. Twelve VES surveys, each of $A B$ spacing $400 \mathrm{~m}$ were carried out in lateritic and granitic rock formations with a view to study the layer response and to delineate the potential zones. Potential aquifer zones were at shallow depth ranging from 10 to $25 \mathrm{~m}$ for the drilled borehole depth of 80-85 $\mathrm{m}$ in every village. Analysis of the result showed a good correlation between the acquired data and the lithologs.

Keywords. Vertical electrical sounding; groundwater; aquifer zones; borehole litholog; Niamey.

\section{Introduction}

Niger is a semi-arid and one of the driest countries in Saharan region where the only source of surface water is the Niger River which lies mostly outside the country and is primarily exploited to irrigate a limited land area. To meet the drinking and domestic needs, the people of Niger primarily depend on groundwater. Detailed knowledge of the aquifer as well as understanding of aquifer composition is important for optimum groundwater exploration especially in hard rock environment. There is little information available on the mechanism and rate of groundwater recharge in Niger. The shallow aquifers of the country are mainly recharged by seasonal rainfall and flooding, but in recent years, rainfall has decreased about 25-40\% compared to the 1930-1960 period (Nicholson et al. 2000). Recharge rates of aquifers in most areas of the country are low, but in some locations the dug wells are yielding sufficient amount of water but are very limited in numbers. Groundwater 
exploration also accompanies lots of uncertainties which needs to be tackled with scientific and systematic approach.

In the early 1990s, hydrodynamics and geochemical methods have been applied at a regional scale to estimate natural groundwater recharge to the unconfined aquifer (Leduc et al. 1997). For the delineation of the aquifer zones, the direct current (DC) resistivity soundings method is one of the most applied geophysical techniques (Van Nostrand and Cook 1960; Zohdy 1974; Koefoed 1979; Patra and Mallick 1980). The electrical resistivity of subsurface is a function of the voids or pores between the particles which allow an electric current to flow through it. Therefore, layers with large pores will have high resistivity value compared to a layer with tighter pore space between its particles. Hence, the subsurface geological variations play an important role and a complex one may add difficulties in exploration.

A total of 12 electrical sounding surveys using Schlumberger array were carried out for groundwater exploration in Niamey, the capital city of Niger. Like any other geophysical methods, DC sounding gives smooth variation as a representative of subsurface changes with depth, which is inverted to extract the subsurface representative model. Five sites were validated with borehole drilling data, providing us all the subsurface information to delineate the potential aquifer zones for drinking water prospecting.

\section{Field study}

The study sites lie in the vicinity of Niamey, the capital city of Niger, West Africa (figure 1) is a metropolitan city covering an area of about $239.3 \mathrm{~km}^{2}$ bisected by the Niger River. The vertical electrical sounding (VES) profiles were 400 $m$ long with some sites adjacent to the Niger River to study the river influence and aquifer system in these areas. It is situated on various formations of the Precambrian West African shield (Liptako-Gourma region in the west) and on Palaeozoic, Mesozoic and Tertiary formations of the Iullemeden basin which extends from Algeria over Mali to Benin and northern Nigeria (Geological setting in the Iullemenden basin, Greigert 1963). The study sites lies in the Precambrian basement shield occurring in the west (Liptako), where its geological boundary is also traced by the river Niger (figure 1). It is partly concealed by dunes and smooth cover sands. Detailed maps were established by Machens (1967) and Ferier (1981), who divided the basement area into Prebirrimian, Birrimian, and Dolerites of younger age. The batholiths are composed of granites, granodiorites and quartz-bearing diorites. Schists with high metamorphism and intercalations of magmatic rocks occur locally between the Prebirimian and the Birimian formations.

The sedimentary formation in the Iullemeden basin can be divided into (a) series of Infracambrianage, (b) the Perm to Cretaceous 'continental 'intercalaire', (c) the upper Cretaceous to lower Eocene 'continental hamadien', (d) the Eocene to Pliocene 'continental terminal', and (e) Quaternary alluvial deposits, dunes and sand deposits (Machens 1967). The 'continental terminal' deposits cover the central part of the lullemeden basin. The base was assigned by Greigert and Pougnet (1967) to the middle Eocene, whereas Machens (1973) indicated an approximatively MioPliocene age for the middle to upper strata. Several types of alluvial deposits of various compositions are found along the Niger River and its tributaries (Thevoz et al. 1994). This formation can be expected to be the main potential aquifer. Therefore, precise identification of the layer thickness is required.

\section{Methodology}

\subsection{DC electrical method}

DC electrical method also knows as vertical electrical sounding (VES) is one of the simplest and most widely used geophysical methods for unravelling subsurface structure for various geotechnical purposes such as groundwater exploration by citing a borehole site, determining depth to bedrock, aquifer system, suitable site of landfill, assessing extent of leachate contamination at landfill site, estimating hydraulic conductivity and natural recharge, etc. (Keller and Frischknecht 1966; Kelley 1977; Patra and Mallick 1980; Kelly and Frohlich 1985; Chand et al. 2004; Chandra 2006). VES provides information about change in the lithology with depth by means of measured resistivity at surface. A number of electrode configurations, viz., Wenner, Schlumberger, dipole-dipole, pole-dipole, Lee-partitioning, buried bipole-pole, Mise-a-la-masse, etc. are used for various purposes depending on the objective. 

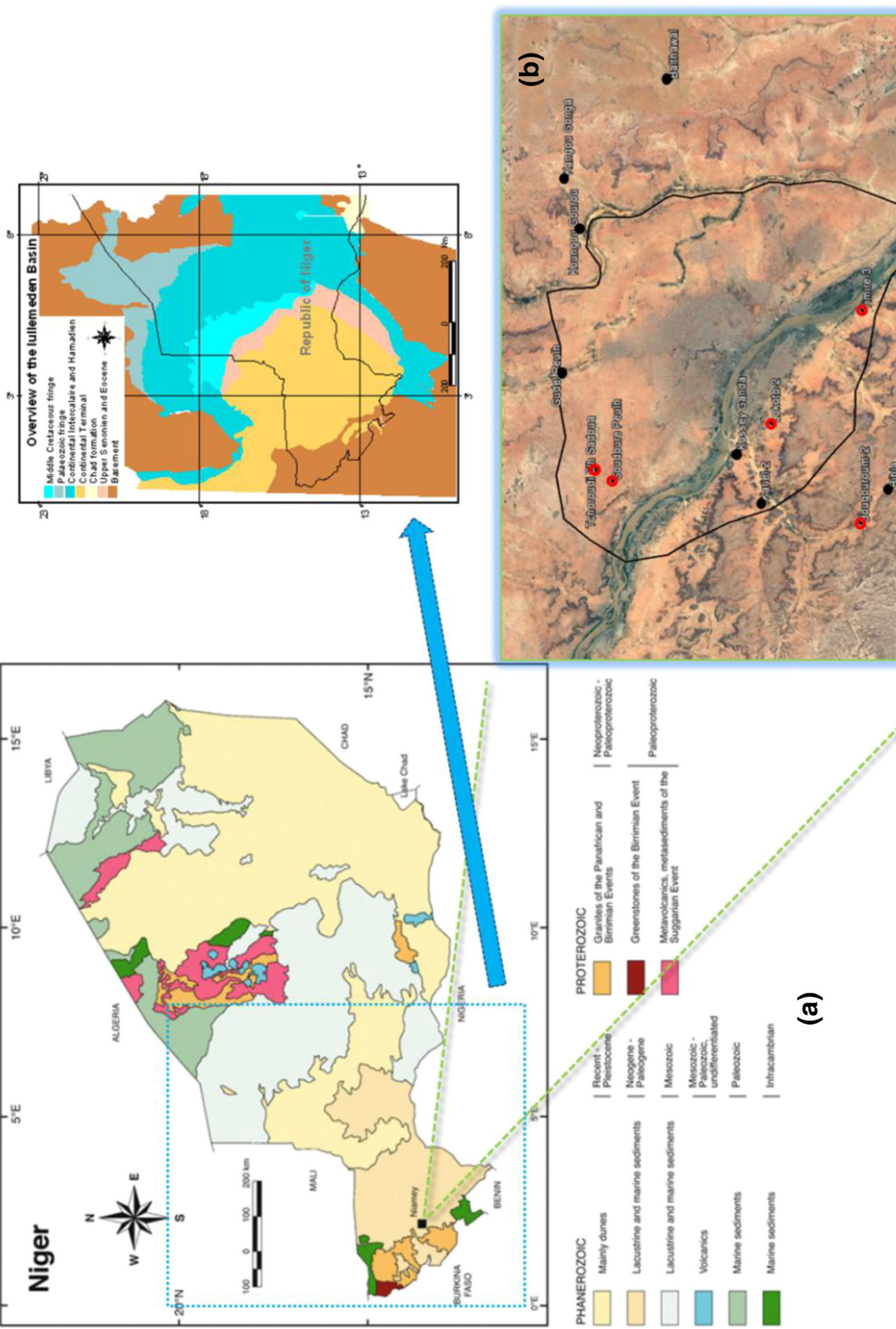
In Schlumberger configuration, all the four electrodes are kept in a line similar to that of Wenner array, but the outer electrode spacing is kept large compared to inner electrode spacing (usually more than five times). For each measurement, only the current electrodes are moved keeping the potential electrodes at the same locations. The potential electrodes are moved only when the signal becomes too weak to be measured. The apparent resistivity $\left(\rho_{a}\right)$ for this configuration is computed with the formulae (equation 1 ):

$$
\rho a=\frac{\left(\frac{A B}{2}\right)^{2}-\left(\frac{M N}{2}\right)^{2}}{M N} \pi\left(\frac{\Delta V}{I}\right)
$$

where $A B$ is the distance between the current electrodes and $M N$ is the distance between the potential electrodes.

The resistivity measurements were made by fully automated resistivity meter named Junior Syscal resistivity meter and Syscal pro-resistivity meter. Typically, a combination of four electrode forms an array where pair of electrodes are used to inject electrical current $(I)$ into the ground and another pair of electrodes are used to measure the resultant potential $(V)$. The greater the distance between the current electrodes, the deeper the investigation (Roy and Apparao 1971a,b). VES determines the resistivity distribution as a proxy of subsurface setup.

The ratio of measured potential difference $(\Delta V)$ between the pair of potential electrodes and injected current $(I)$ and, between current electrodes gives the resistance that changes the dimension of measurement setup. The resistance multiplied with geometrical factor $(K)$ gives apparent resistivity as per equation (2) given below:

$$
\rho=K \frac{\Delta V}{I} .
$$

Geometrical factor is determined based on the electrode setup, which can be seen in various literatures and publication (Bogatyrev 1963; Zohdy Adel 1970; Rhett 2001). The VES data acquisition were carried out with different $A B / 2$ spacing ranging from 200 to $300 \mathrm{~m}$, according to the space available at each respective site. The measured apparent resistivity data is processed using Interpex 1D inversion software and inverted to determine the subsurface structure (Dey and Morrison 1979; Fitterman et al. 1988; Inman et al. 1975; Johansen 1977; Slichter 2004).

\section{Results and discussions}

A total of 12 soundings were carried out, equally distributed along the Niamey region with a view of covering the whole area geologically. VES responses are interpreted below followed by the drilling validation for the data accuracy and reliability.

- Site-1 (Tchoroudi Elh Sadoua Village): This site shows flat topography with sandy soil belonging to lateritic terrain and granites as basement. The 'KH' type' curve's (figure 2) top layer resistivity $(>1400 \Omega \mathrm{m})$ up to $4 \mathrm{~m}$ depth may be attributed to sandy soil followed by sharp increase in resistivity indicating hard laterite zone. The decreasing resistivity may indicate weathered granite or saturated lateritic layer up to $25 \mathrm{~m}$ depth.
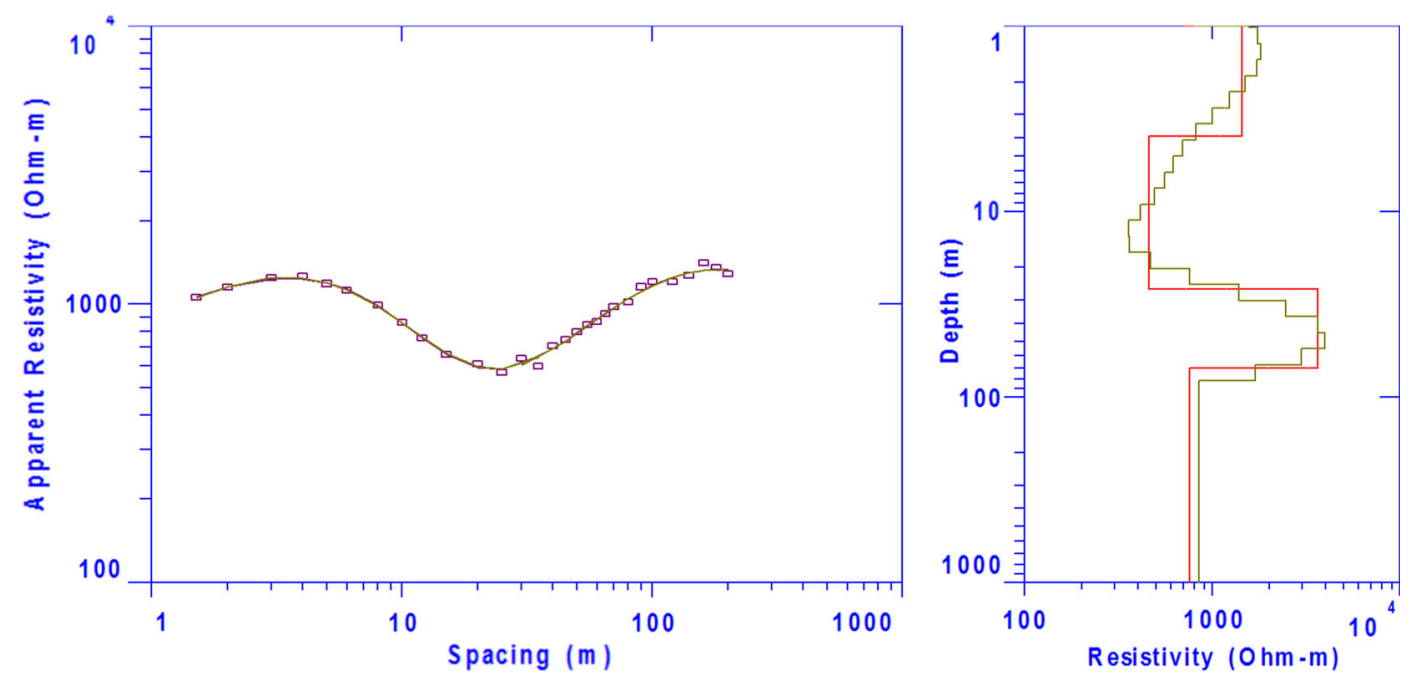

Figure 2. Interpreted VES model of site 1 (Tchoroudi Elh Sadoua Village). 

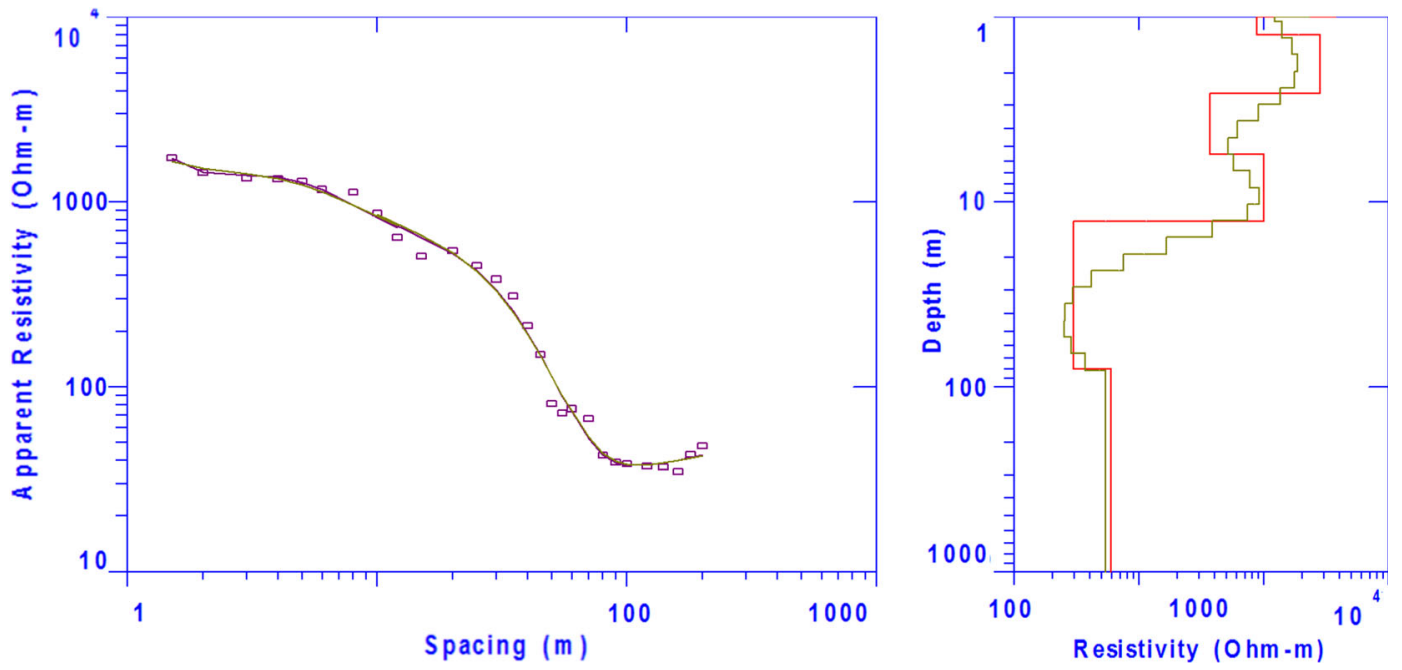

Figure 3. Interpreted VES model of site 2 (Soudoure Peulh Village).
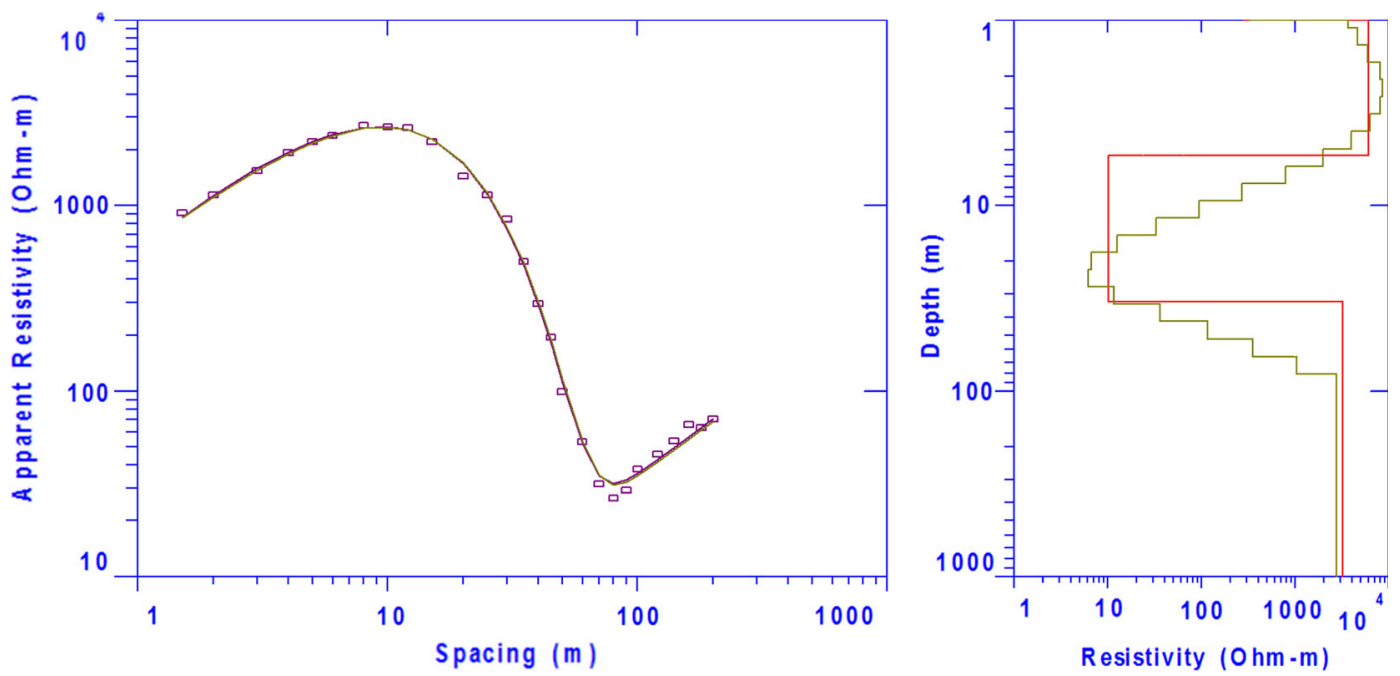

Figure 4. Interpreted VES model of site 3 (Timire 3 Village).

Further high resistive zone $(>3500 \Omega \mathrm{m})$ may indicate that granitic zone up to $55 \mathrm{~m}$ depth and possibly some fractures marking the low resistivity response $(\sim 750 \Omega \mathrm{m})$ is observed beneath this zone extending up to $80 \mathrm{~m}$ depth.

- Site-2 (Soudoure Peulh Village): This site is characterized with flat topography with laterite surface and gneiss out crops observed during the survey. Geological feature shows lateritic patches over surface followed by granite gneiss as basement. The curve (figure 3) is ' $\mathrm{QH}$ ' type with resistivity parameter decreasing with respect to depth. The high resistive top layer $(\sim 2500 \Omega \mathrm{m})$ may be attributed to dry sandy soil up to a depth of $16 \mathrm{~m}$. Resistivity variations is observed in the sand layer due to mixture of loose and compact sand. The sudden low resistive zone beyond $15 \mathrm{~m}$ depth could be attributed to high yielding shallow aquifer zone or weathered and saturated layer beneath the sandy layer and could be a possible reason for such low resistive layers extending up to $70 \mathrm{~m}$ depth.

- Site-3 (Timire 3 Village): This site shows undulating topography, occupied by fine to medium sand. This zone is located over the Niger River bed surrounded by lateritic hills. The curve (figure 4) is ' $\mathrm{KH}$ ' type. The top layer high resistivity $(>6000 \Omega \mathrm{m})$ is attributed to dry sand up to $5 \mathrm{~m}$ deep followed by low resistivity indicating highly saturated or weathered layer up to $40 \mathrm{~m}$ depth. Shallow aquifer may be encountered and its influence could also be the reason for sudden decrease in resistivity. The sudden increase in resistivity 

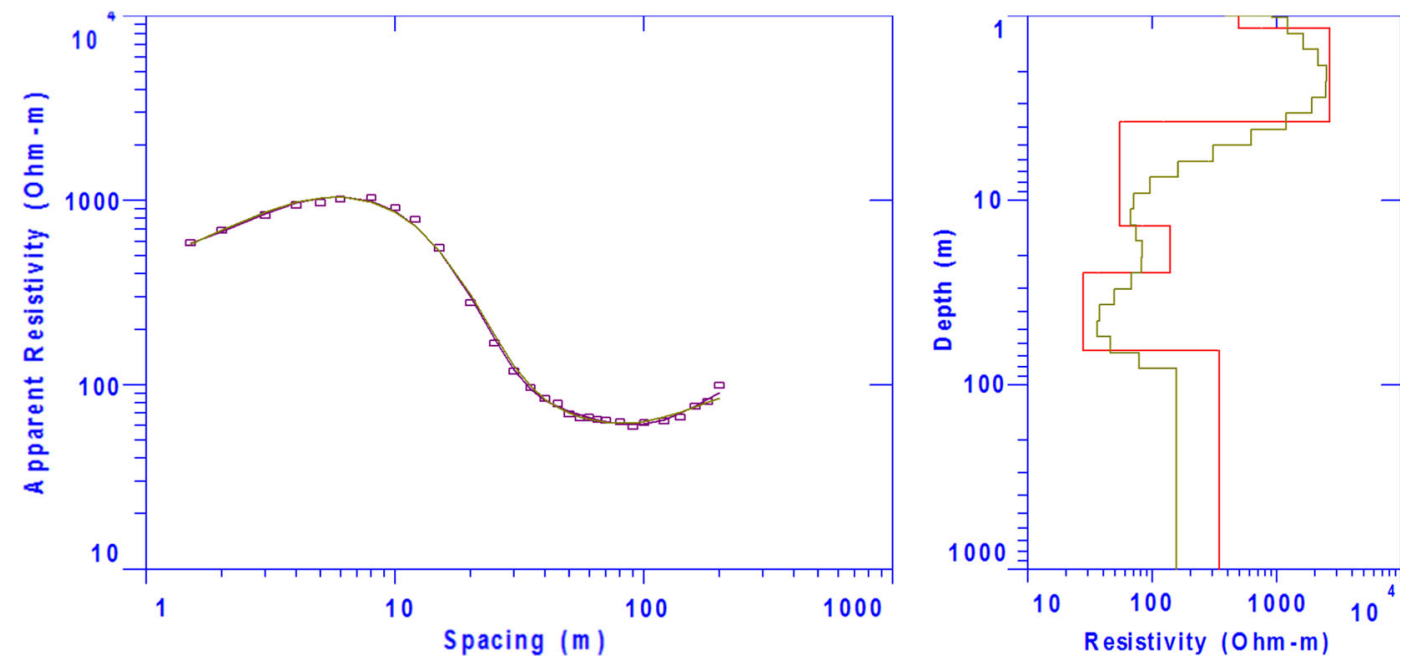

Figure 5. Interpreted VES model of site 4 (Bougouroum 2 Village).
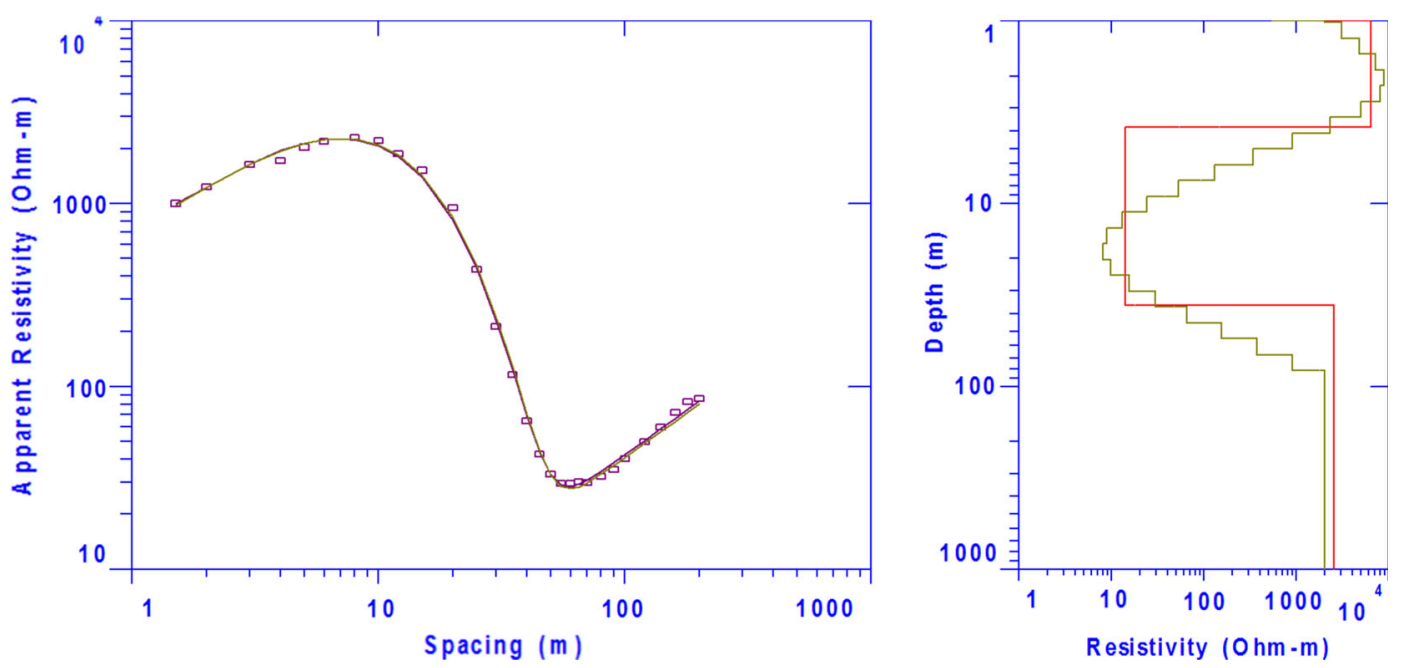

Figure 6. Interpreted VES model of site 8 (Lokoto 2 Village).

could be attributed to granites below extending up to a depth of $80 \mathrm{~m}$.

- Site-4 (Bougouroum 2 Village): The site is characterized with flat topographic surface occupied by fine-to-medium sand. Geologically the area belongs to lateritic terrain. The curve (figure 5) is ' $\mathrm{KH}$ ' type and the increase in resistivity response in the top layer could $(>2500$ $\Omega \mathrm{m})$ be attributed to dry loose sand with some moist beneath dry sand till $15 \mathrm{~m}$ depth. The increase in resistivity parameter of the next layer may indicate dry lateritic zone up to 25 $\mathrm{m}(\sim 200 \Omega \mathrm{m})$. Sudden decrease in resistivity below lateritic layer may indicate highly weathered granitic layer up to $65 \mathrm{~m}$ depth and could be the aquifer zone followed by granites with possible fractures extending up to $85 \mathrm{~m}$ and beyond.
- Site-8 (Lokoto 2 Village): This village is characterized with little undulating topography with silty soil surface. This site is located over the Niger River bed similar to site 3 and surrounded by lateritic hills. The curve (figure 6 ) is ' $\mathrm{KH}$ ' type with top layer resistivity is attributed to dry sand $(>6000 \Omega \mathrm{m})$ up to a depth of $6 \mathrm{~m}$ followed by weathered laterite or highly weathered granite up to a depth of $45 \mathrm{~m}$. The significant rise in resistivity to $2500 \Omega \mathrm{m}$ is attributed to hard granitic layer extending up to $80 \mathrm{~m}$ and beyond.

The interpreted models are classified as geoelectrical sections and compared with the borehole logs which are a sheer tool for correlation and data accuracy. Table 1 presents the geoelectrical stratification for all the VES survey carried out in Niamey, Niger along with the isoresistivity sections 


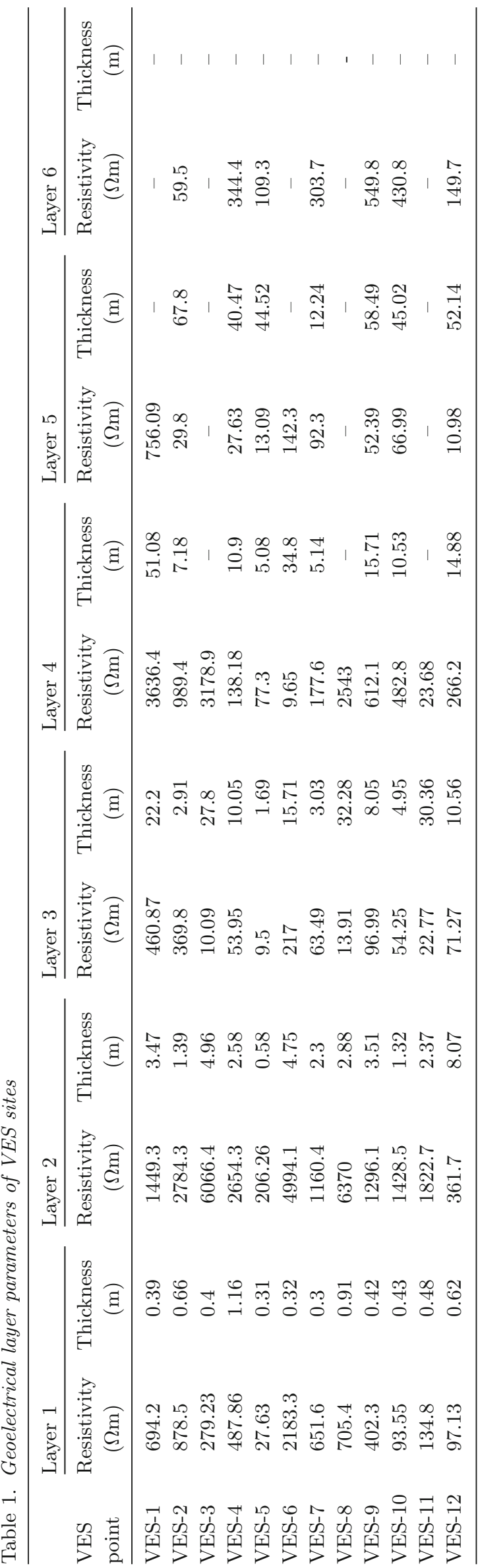

(figure 7). From the isoresistivity map, it can be seen that the top layers are high resistivity layers due to sand domination. Resistivity variations in some layers indicate the effect of the saturated and weathered material. The expected water striking zone indicated from the VES curve response is assumed to be at shallow level $(<25 \mathrm{~m})$ indicating potential shallow aquifer zones. Few fractures may be encountered deep in granites.

\subsection{Drilling and validation}

Verification of the interpreted 1D resistivity results is an important factor for the favourable anomaly identification. The resistivity map and soundings interpretation results clearly show that the vertical extension of the potential aquifer zone ranges less than $20 \mathrm{~m}$. This increases the vulnerability of the groundwater resources. Nevertheless, the granite basement could present local variation in the weathered profile and provides potential aquifer zones that can be missed due to the interpolation of the VES data. Hence a validation by drilling is required. Five sites with available lithologs are briefly interpreted below for the drilling validation.

The interpreted sites are correlated with the drilled lithologs to delineate the potential aquifer zones. The drillings in sites $1-4$ and site 8 between the depths of 80 and $85 \mathrm{~m}$ encountered sand layer, lateritic and granitic layer mostly in all the sites. Some of the drilled bore well sites also show weathered layer and fractures in granites as expected from the VES subsurface model which is adversely affecting the resistivity parameter to a large scale.

Site 1 (Tchoroudi Elh Sadoua Village) drilling results showed good correlation with the VES model (figure 8). The subsurface layers were found to be matching with the VES model. The top sandy layer is extending up to $6 \mathrm{~m}$ deep followed by laterites up to $15 \mathrm{~m}$. The water struck at $15 \mathrm{~m}$ right at the contact zone depicting very shallow aquifer. The decreasing resistivity observed in interpreted VES model was due to the weathered granitic layer up to a depth of $25 \mathrm{~m}$ followed by granites extending up to 80 $\mathrm{m}$ which was marked by high resistivity parameter. A small fracture has also been encountered at $48 \mathrm{~m}$ indicating the probable reason for the sudden low resistivity observed in the granitic layer.

Site 2 (Soudoure Peulh Village) drilling was done to a total depth of $85 \mathrm{~m}$ (figure 9 ). The interpreted model correlated well with the top sandy soil layer 


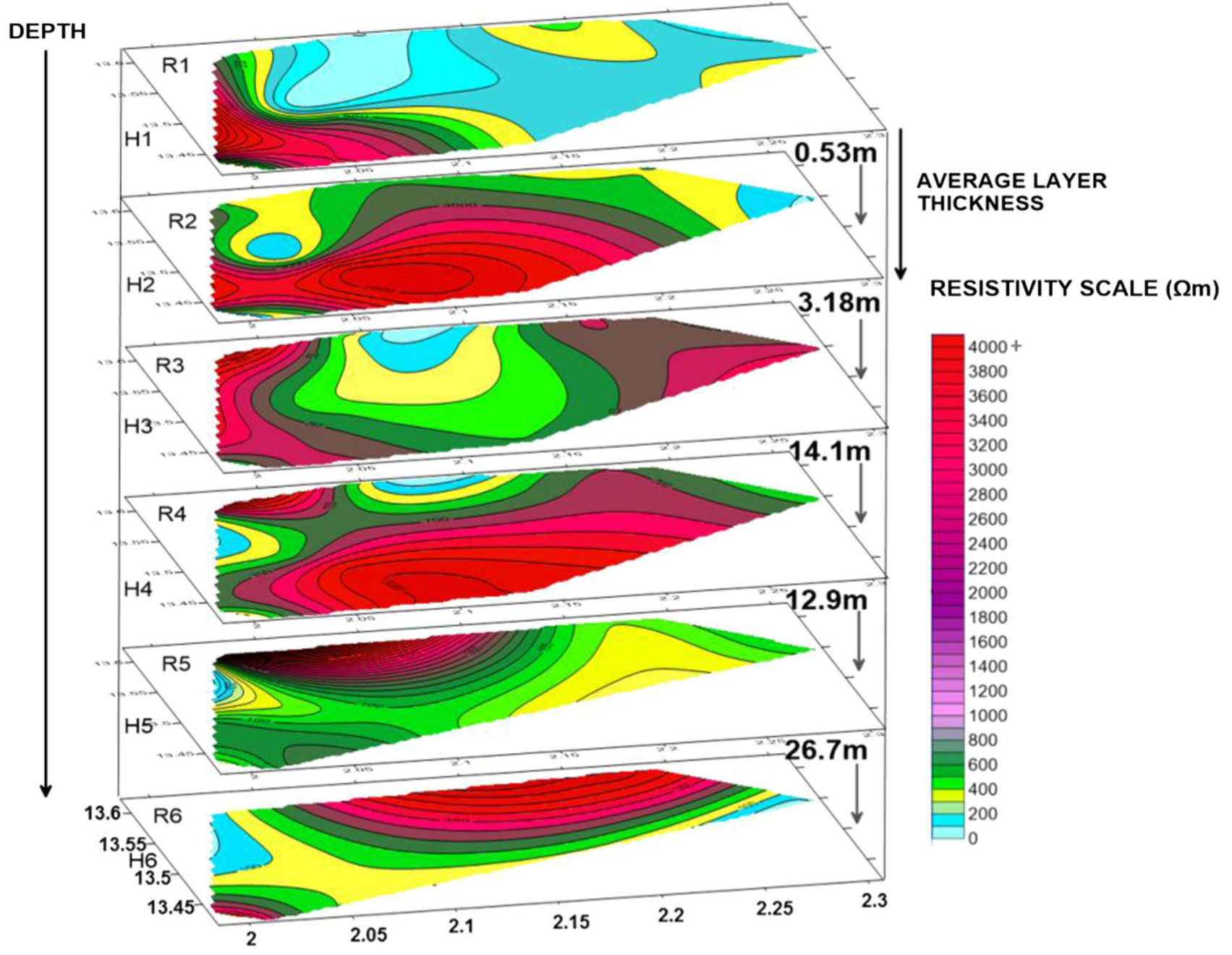

Figure 7. Isoresistivity map of the layer parameters.

extending deep up to a depth of $18 \mathrm{~m}$ followed by low resistivity layer depicting the corresponding layer as a saturated layer due to the effect of shallow aquifer present above. Water struck at 18 $\mathrm{m}$ with high yield (2-3 in.) in the sand-laterite contact zone similar to site 1 . Highly weathered granite up to a depth of $46 \mathrm{~m}$ was encountered below the saturated lateritic layer, which indicates the possible reason for low resistive parameter. Further deep down to $70 \mathrm{~m}$, the fracture zone might have influenced the resistivity parameter which was well interpreted from the VES model.

Site 3 (Timire 3 Village) drilling was also done to a total depth of $85 \mathrm{~m}$ (figure 10). The interpreted model showed sudden decrease in resistivity immediately after the top high resistive layer. Drilling resulted the top high resistive layer as dry sand followed by saturated laterite and weathered granite marked by low resistivity response. Shallow aquifer striking at $18 \mathrm{~m}$ depth possibly influenced the top and below layer's low resistivity up to $35 \mathrm{~m}$ depth. The sudden rise in resistivity clearly shows the presence of granites extending up to $85 \mathrm{~m}$ depth.

Site 4 (Bougouroum 2 Village) drilling results show high resistive sandy top layer up to a depth of $2 \mathrm{~m}$ (figure 11). Water struck at $23 \mathrm{~m}$ depth, adversely affecting the resistivity parameter of top sand layer. Highly weathered granite up to $50 \mathrm{~m}$ depth beneath the dry lateritic layer showed low resistivity response. The sudden increase in resistivity parameter beyond $65 \mathrm{~m}$ depth is due to granitic layer. Fractures in granitic layer resulted in resistivity variations as observed in VES model.

Site 8 (Lokoto 2 Village) showed usual high resistive response in the top sandy layer followed by weathered laterite and weathered granitic layer to a depth of $40 \mathrm{~m}$ was marked by low resistive response (figure 12). Granitic layer beneath the weathered layer showed high resistivity parameter 


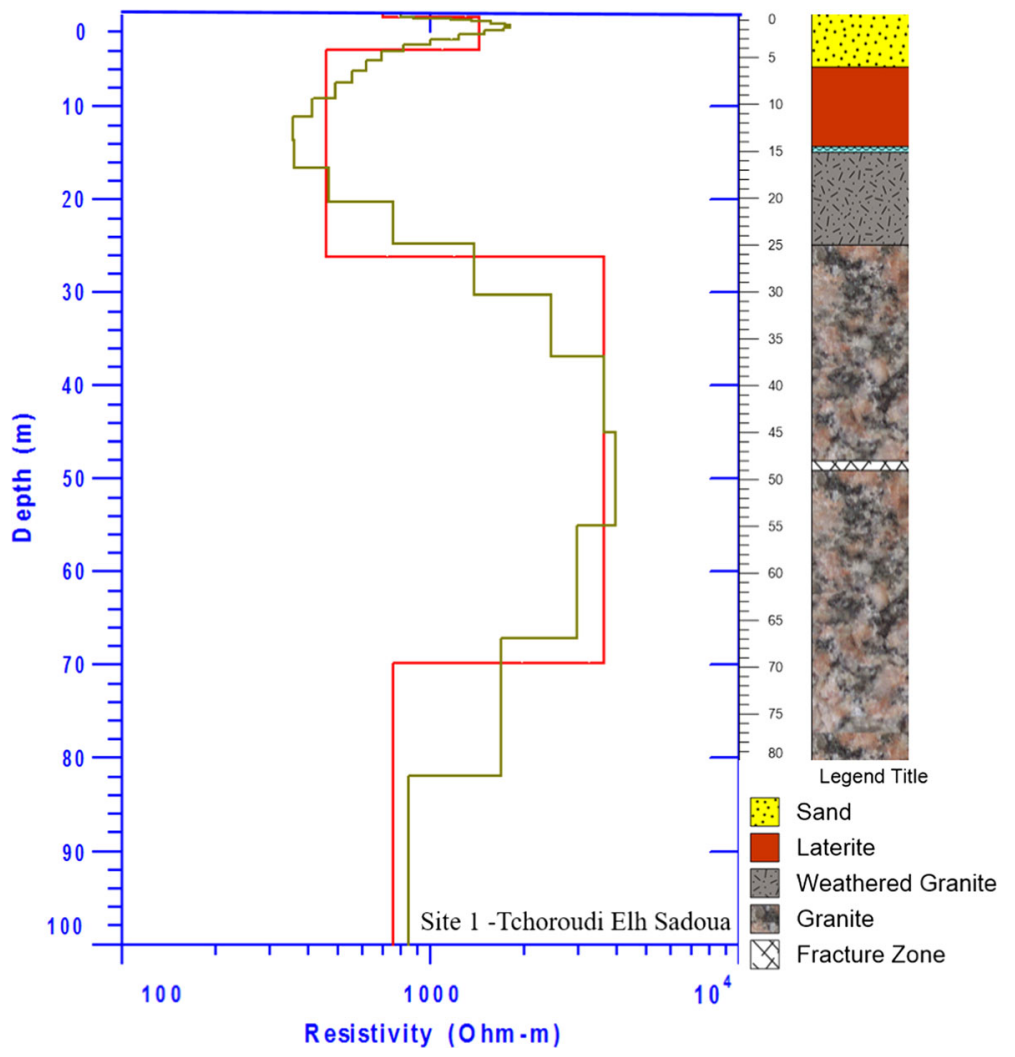

Figure 8. VES model (linear) depth and lithologs validation of study site 1.

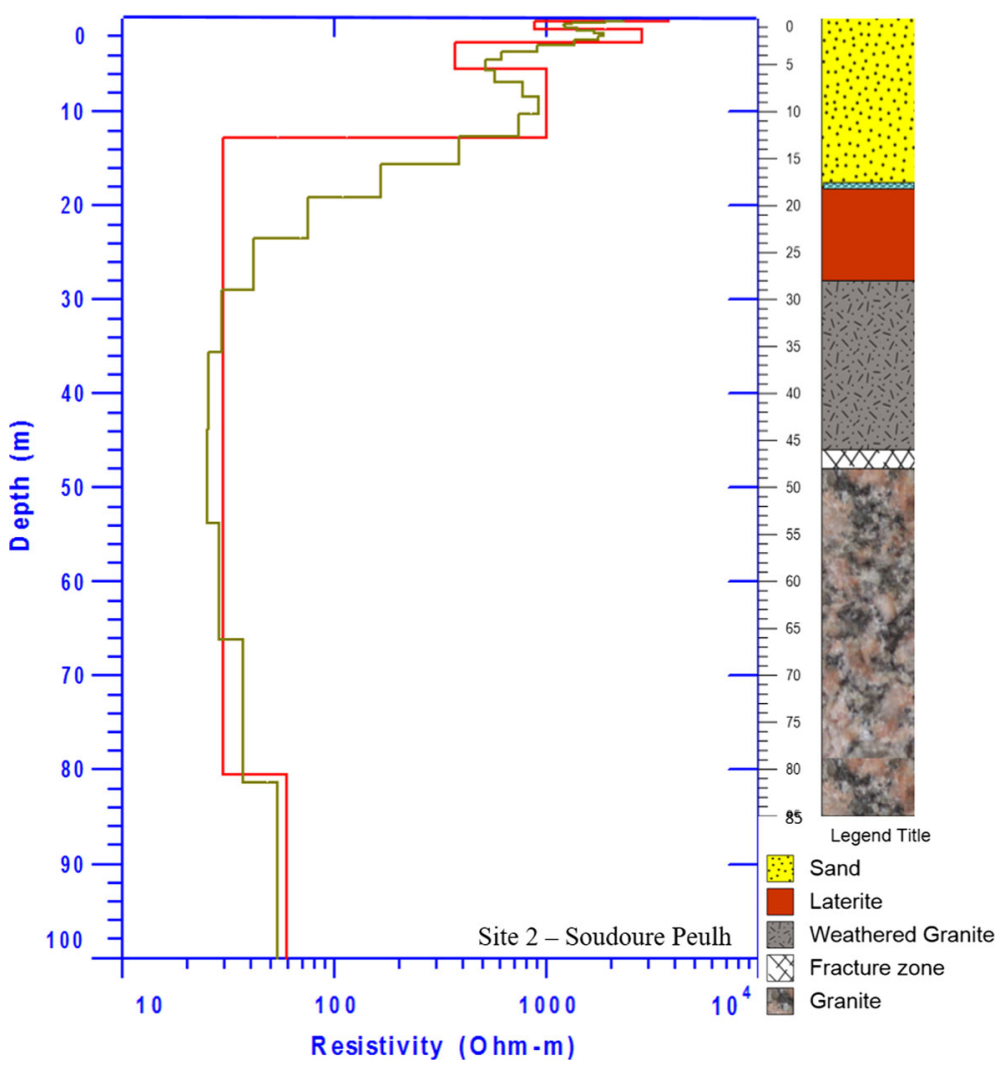

Figure 9. VES model (linear) depth and lithologs validation of study site 2 . 


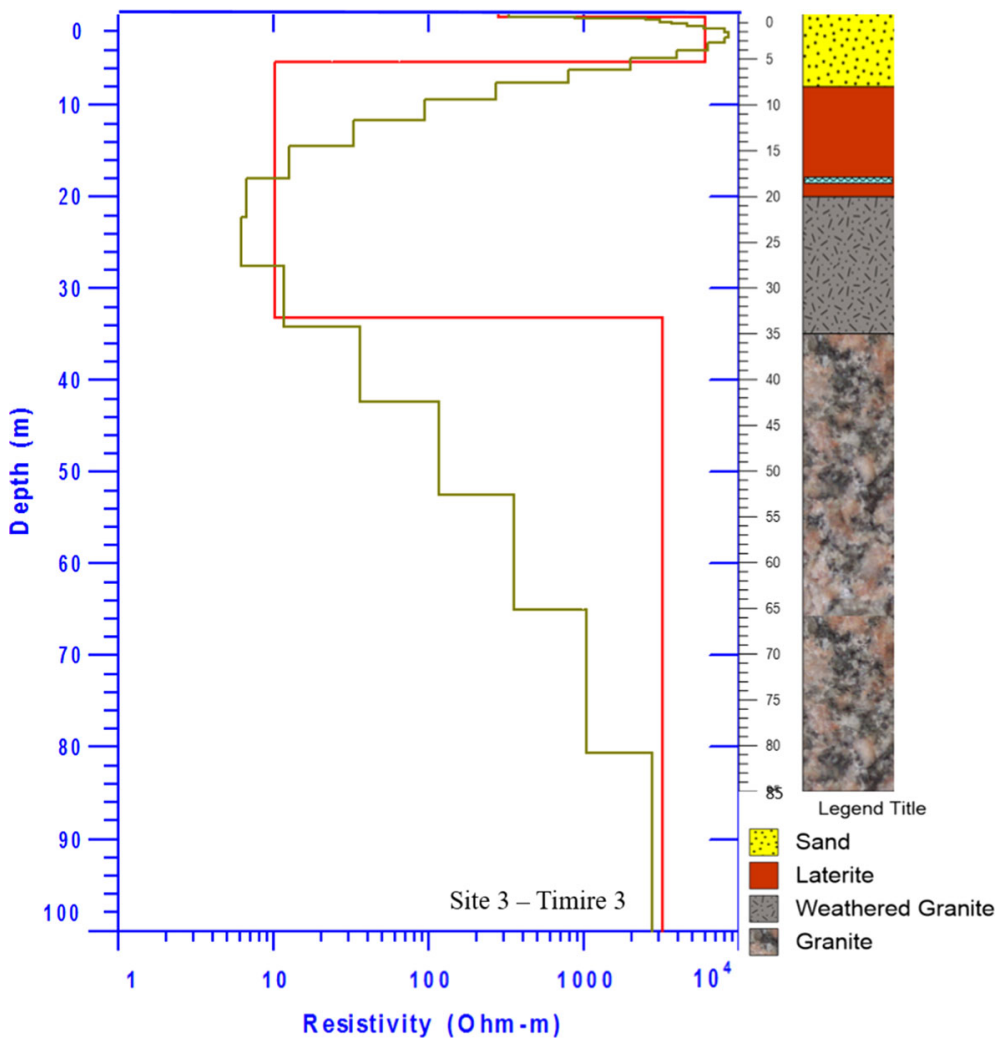

Figure 10. VES model (linear) depth and lithologs validation of study site 3 .

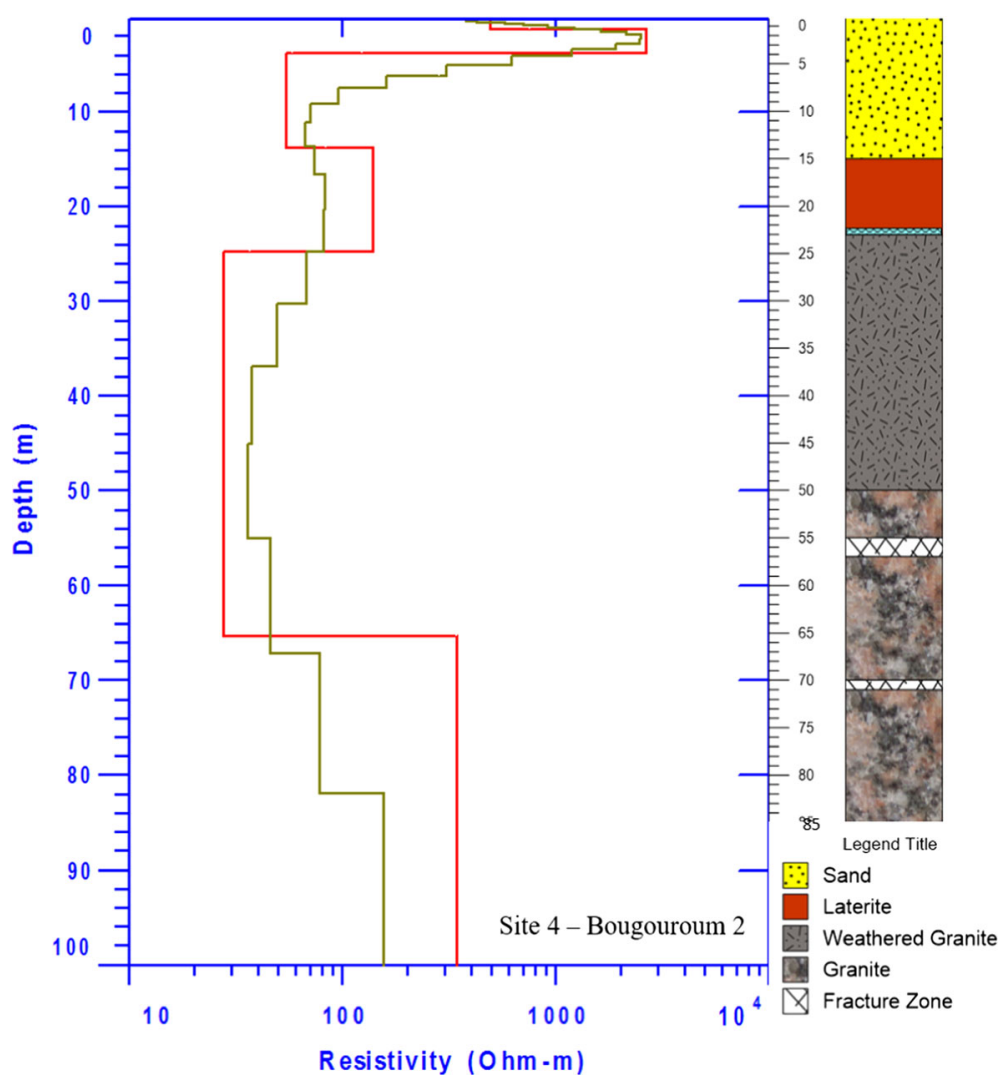

Figure 11. VES model (linear) depth and lithologs validation of study site 4 . 


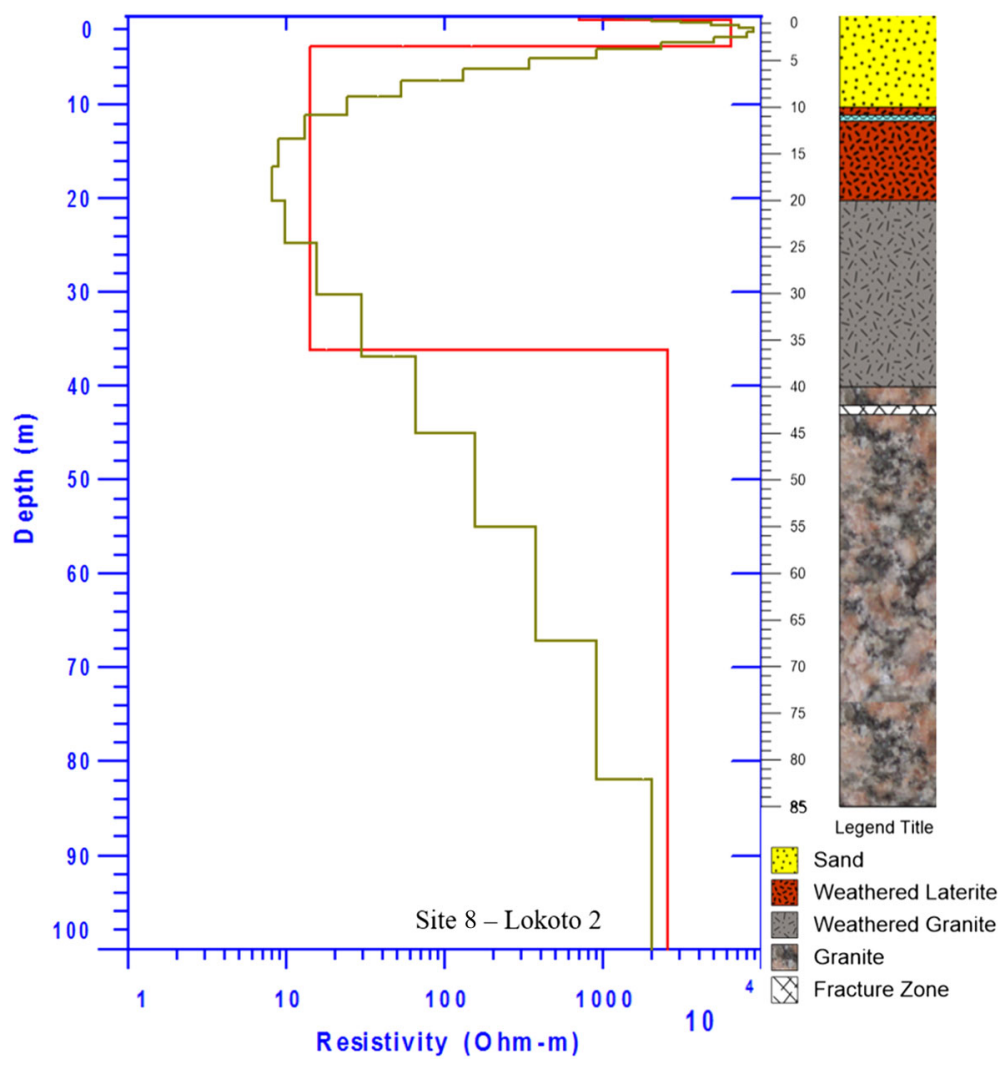

Figure 12. VES model (linear) depth and lithologs validation of study site 8 .

extending up to $85 \mathrm{~m}$ deep. Shallow aquifer at 11 $\mathrm{m}$ also influenced the layer resistivity. A fracture was encountered at $42 \mathrm{~m}$ depth. Drilling result correlated well with the VES model.

It has been observed that in all the sites, the top sand layer $(2-15 \mathrm{~m})$ showed high resistivity contrast whereas decrease in resistivity parameter indicates saturated and highly weathered material which is in good agreement with the interpreted resistivity models. Very shallow aquifers which influenced the layer's resistivity response were delineated efficiently. The high resistive layer is inferred to granite structures extending up to $80 \mathrm{~m}$ and beyond in all the sites. Few expected fractures from the sounding response in the granitic formations were encountered in the lithologs. Hence, with all the positive agreement the drilled bore well lithologs correlate very well with the above interpreted resistivity models.

\section{Conclusion}

VES survey has been carried out in the areas of Niamey city to locate the potential aquifer zones for groundwater prospecting. The areas were surrounded by laterite hills with outcrops of granitic rocks. The subsurface information derived from the sounding data shows that the study areas are mostly lateritic formations followed by granitic formations. The top layer is relatively dry and shows high resistivity with a downward decrease in resistivity for the following few layers which corresponds to the aquifer layer. The high resistive top layer $(>1000 \Omega \mathrm{m})$ depicts the sandy soil layer covering few meters deep. The following saturated lateritic and weathered granitic formations revealed low resistivity contrast. The identified potential aquifer zones were at shallow level ranging from 10 to $25 \mathrm{~m}$ for the drilled borehole up to a depth of 80-85 m, similar to the nearby dug wells revealing very shallow aquifers ranging from 5 to $15 \mathrm{~m}$ deep. The lithologs were very useful to differentiate the layer boundaries and delineate the formations precisely. The sounding response correlates very well with the drilled bore well data and proves that the vertical electrical sounding method is still an efficient method for groundwater prospecting. 


\section{Acknowledgements}

The authors wish to thank the Director, NGRI, Hyderabad for his support, encouragement and the permission to publish this paper. They thank all the Scientists and staffs of Groundwater Department, NGRI for their direct and indirect support for the successful completion of field surveys in Niger. They also acknowledge the staffs of Super Geo Drillers in Niger for their support in field surveys and for providing all the required drilling information. The local assistance of Ministry of Hydraulics, Niger Republic is also acknowledged. Finally, the authors would like to express their thanks to the anonymous reviewer and editor for the critical reviews and valuable suggestions, that has improved the paper.

\section{References}

Bernstone C and Dahlin T 1999 Assessment of two automated DC resistivity data acquisition systems for landfill location surveys: Two case studies; J. Environ. Eng. Geophys. 4 113-121.

Bogatyrev V K 1963 An approximate formula for calculating the geometrical factor of homogeneous bodies of arbitrary shape; Atomic Energy 13(1) 658-660.

Boucher M, Favreau G, Descloitres M, Vouillamoz J M, Massuel S, Nazoumou Y, Bernard Cappelaere and Legchenko A 2009 Contribution of geophysical surveys to groundwater modelling of a porous aquifer in semiarid Niger: An overview; Comptes Rendus Geosci. 341(10) 800-809.

Boucher M, Favreau G, Vouillamoz J M, Nazoumou Y and Legchenko A 2009 Estimating specific yield and transmissivity with magnetic resonance sounding in an unconfined sandstone aquifer (Niger); Hydrogeol. J. 17(7) 1805-1815.

Cappelaere B, Vieux B E, Peugeot C, Maia A and Seguis L 2003 Hydrologic process simulation of a semiarid, endoreic catchment in Sahelian West Niger, Africa; J. Hydrol. 279 $244-261$.

Chand R, Chandra S, Rao V A, Singh V S and Jain S C 2004 Estimation of natural recharge and its dependency on subsurface geoelectric parameters; J. Hydrol. 299 $67-83$.

Chandra S 2006 Contribution of geophysical properties in estimating hydrogeological parameters of an aquifer; Unpublished Ph.D. Thesis, BHU, Varanasi, 176p.

Cook P G, Walker G R and Jolly I D 1989 Spatial variability of groundwater recharge in a semiarid region; J. Hydrol. 111 195-212.

Dahlin T 1996 2D resistivity surveying for environmental and engineering applications; First Break 14 275-283.

Dahlin T 2001 The development of DC resistivity imaging techniques; Comput. Geosci. 27 1019-1029.

Dey A and Morrison H F 1979 Resistivity modelling for arbitrarily shaped 2-dimensional structures; Geophys. Prospect. 27 106-136.

Ferier P 1981 Carte géologique à 1:100 000, Tillabery 9-15. Republique du Niger, BRGM.
Fitterman D V, Meekes J A C and Ritsema I L 1988 Equivalence behavior of three electrical sounding methods as applied to hydrogeological problems. 50th EAEG meeting, The Hague, The Netherlands, Expanded Abstracts.

Gowd S S 2004 Electrical resistivity surveys to delineate groundwater potential aquifers in Peddavanka Watershed, Anantapur District, Andhra Pradesh, India; J. Environ. Geol. 46 118-131.

Greigert J 1963 Description des formations crétacées et tertiaires du Bassin des Iullemeden, Editions du BRGM, Paris, $234 \mathrm{p}$.

Greigert J and R Pougnet 1967 Essai de description des formations géologiques de la République du Niger; Editions du Brgm, Paris, 273p.

Guérin R, Descloitres M, Coudrain A, Talbi A and Gallaire R 2001 Geophysical surveys for identifying saline groundwater in the semi-arid region of the central Altiplano, Bolivia; Hydrol. Process. 15(17) 3287-3301.

Herman Rhett 2001 An introduction to electrical resistivity in geophysics Am. J. Phys. 69(9) 943-952.

Inman J R, Ryu J and Ward S H 1975 Resistivity inversion; Geophysics 38 1088-1108.

Johansen H K 1977 A man/computer interpretation system for resistivity soundings over a horizontally stratified earth; Geophys. Prospect. 25(4) 667-691.

Kelley W E 1977 Geoelectrical sounding for estimating hydraulic conductivity; Ground Water 15 420-425.

Keller G V and Frischknecht F C 1966 Electrical Methods in Geophysical Prospecting; Pergamon, New York.

Kelly W E and Frohlich R K 1985 Relation between aquifer electrical and hydraulic properties; Ground Water 23(2) 182-189.

Kresnic N 2007 Hydrogeology and Groundwater Modeling, 2nd edn, CRC Press, Boca Raton.

Koefoed O 1979 Geosounding Principles 1. Resistivity Sounding Measurements, Elsevier Scientific Company, Amsterdam.

Leduc C, Bromley J and Schroeter P 1997 Water table fluctuation and recharge in semi-arid climate: some results of the HAPEX-Sahel hydrodynamic survey (Niger); Journal of Hydrology, 188-189, pp. 123-138

Machens E 1967 Notice explicative sur la carte géologique du Niger Occidental à l'échelle 1/200000; Editions du Bureau de Recherches Géologiques et Minières. Paris XVe. 35p.

Machens E 1973 Contribution à l'étude des formations du socle cristallin et de la couverture sédimentaire de l'Ouest de la République du Niger. Publicatiojn no. 4. Editions du Bureau de Recherches Géologiques et Minières. ParisXVe. 158p.

Massuel S, Favreau G, Descloitres M, Le Troquer Y, Albouy Y and Cappelaere B 2006 Deep infiltration through a sandy alluvial fan in semiarid Niger inferred from electrical conductivity survey, vadose zone chemistry and hydrological modelling; Catena 67(2) 105-118.

Nicholson S E, Some B and Kone B 2000 An analysis of recent rainfall conditions in West Africa, including the rainy seasons of the $1997 \mathrm{El} \mathrm{Niño} \mathrm{and} \mathrm{the} 1998 \mathrm{La}$ Niña years; J. Climate 13(14) 2628-2640.

Patra H P and Mallick K 1980 Geosounding principles: 2. Time-varying geoelectric soundings; Elsevier, Amsterdam.

Roy A and Apparao A 1971a Depth of investigation in direct current methods; Geophysics 36 943-959. 
Roy A and Apparao A 1971b The two-electrode system of resistivity prospecting, presented at the symposium on 'Exploration techniques for metalliferous deposits' held at Khetri, Rajasthan, India, March 27-28, 1971.

Slichter L B 2004 The interpretation of the resistivity prospecting method for horizontal structures; J. Appl. Phys. 4 307-322.

Todd D K 1980 Groundwater Hydrology; 2nd edn, John Wiley and Sons Inc., New York, 535p.

Telford M, Geldart L P, Sheriff R E and Keys D A 1976 Applied geophysics; Cambridge University Press, Cambridge.

Thevoz C, Ousseini I and Bergeoing J P 1994 Aspects géomorphologiques de la vallée du Niger au sud de Niamey (secteur Saga Gourma-Gorou Kirey); Rev. Géographie Alpine, Au Contact Sahara-Sahel. 1 65-83.

Van Nostrand R E and Cook K L 1960 Interpretation of resistivity data; USGS Professional Paper 499, Washington.

Van Overmeeren R A and Ritsema I L 1988 Continuous vertical electrical sounding; First Break 6 313-324.

Zohdy Adel A R 1970 Variable azimuth Schlumberger resistivity sounding and profiling near a vertical contact. No. 1313-A. US Govt. Print. Off.

Zohdy A A R 1974 Use of Dar Zarrouk Curves in the interpretation of vertical electrical sounding data - (new techniques in direct-current resistivity exploration); Geol. Surv. Bull. 1313-D, 1974-677-306/18.

Corresponding editor: Subimal GHosh 